\title{
SUPPLIER MANAGEMENT PRACTICE AND SERVICE QUALITY: CRITICAL REVIEW ON MEDIATING ROLEOFOUTSOURCING SERVICE PROVIDER CAPABILITIES
}

\author{
Man Wah Conny Wang ${ }^{1}{ }^{*}$, Cheng Ling Tan ${ }^{1}$, and Nabsiah Abdul Wahid ${ }^{1}$ \\ ${ }^{1}$ Graduate School of Business, Universiti Sains Malaysia, 11800 USM, Penang, Malaysia
}

\begin{abstract}
The increased demand for properties become part of the investment assets in Hong Kong. Facilities management practitioners need to face the challenges of proper maintenance and services to maintain the value of the property assets. Based on the literature, facilities management companies can benefit from the share of market strength through their service providers. Hence, with the increasing demand for quality services, facilities management companies need to strive for survival and maintain their business power in the industry. Nonetheless, literature shows that the service quality in facilities management is lacking. Past research put less attention in conducting a critical review of research articles related to supplier management practice in facilities management industry. Additionally, the review identified a missing link of supplier management practice and service quality with presence of outsourcing service provider capabilities as a mediator. The critical review outcome assists the development of a framework to link the relationships among supplier management practice, outsourcing service provider capabilities and service quality. This paper attempts to provide important supports for facilities management companies to capture the disposition of the company. For having better leverage organizational context by exploiting relationships with outsourcing service providers, this paper extends Resource-based View Theory into outsourcing and service quality context. Thus, this paper attempts to fill important gaps in the above contexts. Finally, this paper suggests several recommendations for future study directions in the area of service quality in facilities management industry.
\end{abstract}

ARTICLE HISTORY

Received: 3-6-2020

Accepted: 1-9-2020

\section{KEYWORDS}

Service Quality, Supplier Management, Outsourcing Service,

Provider Capabilities

\section{INTRODUCTION}

Some cities like Hong Kong has made the demand for properties become part of the investment assets. Facilities management practitioners need to face the challenges of proper maintenance and services to maintain the value of the property assets. However, it is difficult for facilities management companies to equip with all aspects of professions to cover the extensive scopes of services including legal knowledge, technical services, security services, horticulture services, etc. This point of view is supported by Alexander (2003) that facilities management has rapidly developed to involve various disciplines, vocation, and business services. In light of the complicated scopes of services to be provided, facilities management companies should deploy the necessary expertise in respective ranges of services involved in managing the properties. Therefore, it is unavoidable to increase the costs of operation.

The study of Gottschalk and Solli-Sæther (2005) revealed that due to scarcity of resources, companies should focus on valuable inputs. By shifting the non-core business to the service providers, facilities management companies are able to allocate resources to the scope with a competitive advantage to develop the business further. In addition, the company does not require giving up the business opportunities in the field which does not specialize by outsourcing to a service provider, it can also control both the main business areas and supplementary business opportunities. Therefore, the company does not require to invest in resources in the field and able to allocate resources to focus on its strength. Logan (2000) realized that it was most profitable for an enterprise to focus on the works they did well.

In order to face the challenge of increasing costs, it is a common practice in the facilities management industry to outsource part of the services to service providers in the respective fields to assist in supporting their services. McBlaine and Moritz (2002) defined outsourcing as a partnership relation that professional services provided. Holcomb and Hitt (2007) also stated that outsourcing was the behavior of an organization relying on the provision of specialized capabilities to supplement the existing capabilities of the organization. Different scholars have a similar view that one of the reasons for outsourcing is cost control. Lehtonen and Salonen (2006) viewed that the partners involved in outsourcing were able to generate synergies to develop concepts in the form of efficiency and ultimately save costs. By adopting an outsourcing strategy, Gilley and Rasheed (2000) pointed out that costs could be reduced and the organization can shift to their core competence.

A tight working relationship of outsourcing which depends between the principal and the service provider can strengthen the competition power among the business world. Mentzer, Min, and Zacharia (2000) also pointed out in their study that operational partnering is intended to seek improvement in efficiency and effectiveness. Through the process 
of outsourcing, the trust-forming social exchange process contained elements of inter-firm adaptations in a business relationship that might be positively related to the two parties (Hallen, Johanson, and Seyed-Mohamed, 1991). The process could strengthen both parties in the future business working relation. Gainey and Klaas (2003) also found that the partnership of the parties might begin with arms-length relationships and be disciplined only through market-based mechanisms. However, this situation might transform over time. The question is how the facilities management practitioners can support their outsourcing service providers in achieving high capabilities to enhance the service quality and competitive advantage.

This paper attempts to link the relationships among supplier management practice, outsourcing service provider capabilities, and service quality of facilities management companies. Supplier management is considered from quality management practices; outsourcing service provider capabilities are considered within the outsourcing context; while service quality is considered within the organizational context i.e. facilities management industry.

Based on the literature which includes empirical studies, facilities management companies can benefit from the share of the market strength from their service providers. Talib, Rahman, and Qureshi (2013) attempted to adopt quality management practices, including supplier management practices, to investigate whether they are positively related to service quality. The empirical study of Prajogo, Chowdhury, Yeung, and Cheng (2012) supported the hypothesis of supplier assessment is positively associated with a firm's quality performance. Outsourcing is important in the facilities management industry. With the increasing demand for quality services, facilities management companies need to strive for survival and maintain their business power in the industry. As it is difficult for a company to employ different professionals to provide services in various aspects of facilities management, outsourcing is a way to assist facilities management companies to remain market shares in the industry without diversifying their resources. By adopting the strategy of outsourcing such as the mediating role of outsourcing service provider capabilities, facilities management companies can meet the target of cost control to allocate resources to expand their core business without giving up the business opportunities in developing the market by using the means of outsourcing to service providers. In this connection, facilities management companies can enhance service quality and obtain competitive advantages to strengthen their competitiveness in the market. This can be achieved by adopting the high outsourcing service provider capabilities to strive for better business opportunities.

This paper attempts to provide a critical review examining the conceptual and prescriptive statements in the literature on the impact of the outsourcing service provider capabilities between service quality and supplier management for quality management practices. The critical review was performed to develop the three hypotheses in the relationships between supplier management for quality management practices, outsourcing service provider capabilities, and service quality of facilities management companies. This paper proposes to conduct a questionnaire survey for testing whether high outsourcing service provider capabilities will mediate the impact of supplier management on quality management practices and service quality of facilities management companies in Hong Kong. Smart-PLS 3.0 software is recommended to be used for the analysis of the direct and indirect relationships between supplier management practice, outsourcing service provider capabilities, and service quality.

\section{LITERATURE REVIEW}

\section{Service quality}

Service quality in this paper refers to the focus on meeting customers' needs and requirements and it is a measure of how the service delivered matches customers' expectations. Delivering quality service means conforming to customer expectations consistently. The definition is adapted from Lewis (1993) cited in Parasuraman, Zeithaml, and Berry (1985). Service quality is conceptualized according to the five dimensions including tangibles, reliability, responsiveness, assurance, and empathy (Parasuraman, Zeithaml, \& Leonard, 1988). The meeting of customers' needs and requirements can be achieved by outsourcing service providers based on the roles and responsibilities set forth by the facilities management companies through the facilities management practitioners. It indicates how well (1) facilities management practitioners perform their quality management practices to manage the outsourcing service providers, and (2) outsourcing service providers perform their services which were assigned by facilities management practitioners. As outsourcing service providers largely contribute to the non-core business of facilities management companies, their capabilities greatly affect the service quality of facilities management companies. Since the important contribution of outsourcing service providers to the non-core business of facilities management companies is highlighted, research into what drives service quality of facilities management companies has attracted attention from scholars and facilities management researchers.

Past research in examining service quality of facilities management companies has been primarily on factors related to outsourcing service providers. These are often challenged by the reason of not being a motivator on the enhancement of service quality of facilities management companies. However, the examination of a direct influence of factors related to outsourcing service providers on service quality of facilities management companies is still unable to explain the variance in service quality of facilities management companies. Subsequently, scholars proposed that studies related to service quality of facilities management companies can be examined through an exploration of quality management practices. The determinant of supplier management for quality management practices is one of the controllable organizational factors that can influence outsourcing service provider capabilities.

Since supplier management is known as an influence on outsourcing service provider capabilities, it is suggested by scholars that quality management factors can be the focus. Based on past research, management companies were found to be related to supplier management in quality management practices (Prajogo et al., 2012). However, the mechanism 
of how supplier management practice influences the service quality of facilities management companies remains a question. Scholars believed that supplier management for quality management practices influences outsourcing service provider capabilities, which in turn, leads to service quality of facilities management companies.

\section{Supplier management practice}

Supplier management for quality management practices in this paper refers to the management of a supplier in which a supplier can be a distributor, source, or service provider. This supplier is also the organization that supplies products and services to its customers via outsourcing to facilities management companies. The definition is adapted from AlHawary and Abu-Laimon (2013).

In this paper, the construct of supplier management was adapted from Chuah, Wong, Ramayah, and Jantan (2010). They initiated that supply chain management means companies are focusing on the business in terms of supply chain instead of a single run. Nowadays, effective supplier management practice is crucial in satisfying the changing needs of customers while the supply chain has to be responsive in providing prompt and reliable delivery of high-quality services at a low cost. This is a very critical insight for the organizations to develop a good competitive advantage as well as high service quality to maintain excellence in operating the business. Responsiveness of the supply chain can be enhanced through the suppliers' performance, but not solely depend on the organization's performance (Wong \& Wong, 2008). Hence, in the facilities management industry, it is important to consider the issue of supplier management practice that encompasses planning, implementing, developing, and monitoring the company's relationship with its outsourcing service providers.

Hsu, Tan, Kannan, and Keong Leong (2009) indicated that quality management and supply chain management techniques and tools must be implemented concurrently to achieve superior financial and business performance through the examination of the relationship between operational quality practices, supply chain management practices, and firm performance. Moreover, positive direct and indirect relationships exist between supply chain integration and financial performance which was proved by the investigation of Vickery, Jayaram, Droge, and Calantone (2003) in the performance implications of an integrated supply chain management strategy. In addition to the study of Tan (2002) that claimed certain supply chain management practices positively impact firm performance, Wisner (2003) also demonstrated a positive relationship between supply chain management and firm performance through a theoretical framework for supplier and customer management. Zineldin and Jonsson (2000) posited that developing supplier partnerships and longterm relationships can increase the organization's competitiveness as well as enhance performance. Zakuan, Yusof, Laosirihongthong, and Shaharoun (2010) cited in Talib et al. (2013) also indicated that cooperation and a long-term relationship with the suppliers can obtain effective supplier management. Hence, this is possible to support that supplier capability can lead to time efficiency, high quality, and rapid integration of new technologies. By increasing outsourcing activities, facilities management companies rely to a greater extent on their partners and must effectively manage their outsourcing service providers to remain competitive.

\section{Outsourcing service provider capabilities}

Outsourcing service provider capabilities in this paper refer to the ability of outsourcing service provider to apply strategic potential in the industry/market. This includes the ability of the outsourcing service providers in using and deploying competencies to achieve business objectives by satisfying customer needs such as cost, quality, flexibility, and on-time delivery. The definition is adapted from Perunović, Mefford, and Christoffersen (2012).

McBlaine and Moritz (2002) defined outsourcing as a partnership relation that professional services provided. They stated that the service providers could contribute to solutions that work, offering broad and evolving services in order to provide financial and transition expertise to the facilities management companies. Thus, outsourcing service providers performed the operations of facilities management services.

Technical competence capability consists of the extent to which outsourcing service providers can deliver services and perform functions efficiently and cost-effectively (Goles, 2003). It initiated high outsourcing service provider capabilities such as a certain amount of technical proficiency for any outsourcing arrangement to be successful. In addition to being a necessary condition for outsourcing success in the facilities management industry, outsourcing service provider capabilities can enhance competitiveness by controlling related costs, delivering systems in a timely manner, and effectively implementing solutions to achieve business objectives to the extent of supporting corporate objectives such as service quality. This paper attempts to focus on outsourcing service provider capabilities related to supplier management for quality management practices and service quality.

In Hong Kong, outsourcing is a common practice in the facilities management industry. The service quality of facilities management companies is inevitably linked up with the service quality of the outsourcing service providers. The outsourcing service provider capabilities influence the service quality of facilities management companies. In fact, outsourcing is the act of appointing a separate organization with a contract base to provide services that could be performed by in-house staff. In response to the high demand for skilled and professional services in the facilities management industry, facilities management companies to a large extent rely on the outsourcing service providers to shift the scopes of works that are not under their expertise in order to reduce costs. Furthermore, if outsourcing service providers put out a good performance and high capabilities, the service quality of facilities management companies possibly can be enhanced. 


\section{RESEARCH FRAMEWORK AND HYPOTHESES}

\section{Research framework}

Concerning the above literature review and discussion, the research framework was shown in Figure 1. It was developed to incorporate the influence of supplier management for quality management practices and outsourcing service provider capabilities on service quality of facilities management companies.



Figure 1. Research framework

The research framework was developed based on the Resources-based View Theory (RBV). According to Peteraf and Barney (2003), RBV theory examines the performance differences of organizations based on their resources. It focuses on efficiency-based differences, instead of on other ways in which organizations could be different, such as market power, collusion, or strategic behaviors. The competitors of an organization can be identified by the similarity of their products, resources, capabilities, and substitutes. RBV theory is a strategic management point of view which concerns how firms formulate and implement strategies in order to accomplish the desired performance goal (Lee, Huynh, Kwok, \& Pi, 2000). With reference to the underlying theory of RBV, the research framework of this paper attempts to investigate whether supplier management for quality management practices will positively influence the service quality of facilities management companies through the mediating variable of outsourcing service provider capabilities.

\section{Research hypotheses}

Outsourcing service providers who reciprocate the influence of supplier management for quality management practices should engage in high capabilities to achieve the enhancement of service quality. Based on the past studies, both literature review and empirical investigation supported a positive relationship between the relevant management practices and capabilities (Akgün, Ince, Imamoglu, Keskin, and Kocoglu (2014); Ouakouak, Ouedraogo, and Mbengue (2014); Peng, Quan, Zhang, and Dubinsky (2016); Hong, Zhang, and Ding (2018)). Hence, it can be hypothesized that:

H1: Supplier management for quality management practices has a positive influence on outsourcing service provider capabilities.

Capabilities influence outcomes such as firm performance and success which are consistently associated with increased service quality. Past studies examining capabilities largely supported the notion that high capabilities enhance service quality (Goles (2003); Ranganathan and Balaji (2007); Perunović, Christoffersen, and Mefford (2012); Plugge, Bouwman, and Molina-Castillo (2013); Pratap (2014); Tseng and Lee (2014); Tseng (2016)). Based on the literature review and empirical investigation, it is proposed that:

\section{H2: High outsourcing service provider capabilities have a positive influence on service quality.}

With reference to the abovementioned hypothesis, past studies were examining the direct relationship between (1) management practices and capabilities; and (2) capabilities and service quality. The mediating effect of outsourcing service provider capabilities received relatively lesser attention. Capabilities have been examined by various scholars as a mediator in the relationship between organization performance and service quality (Akgün et al. (2014); Ouakouak et al. (2014); Peng et al. (2016)). The findings of the above studies correlate with the study outcome of Hong et al. (2018) in which capabilities partially mediate the relationship between management practice and performance. Although outsourcing service provider capabilities have not been studied as a mediator between supplier management for quality management practices and service quality, it can be proposed that:

H3: Outsourcing service provider capabilities mediate the relationship between supplier management for quality management practices and service quality. 


\section{DISCUSSION}

To test the validity and usefulness of the proposed model of this study, it is suggested for an empirical study to be conducted using a quantitative approach that investigates possible correlation amongst the independent variables, mediating variables and dependent variables in the model to be designed. By doing so, the proposed relationship between supplier management for quality management practices (independent variable) and outsourcing service provider capabilities (mediating variable), between outsourcing service provider capabilities (mediating variable) and service quality (dependent variable); and between supplier management for quality management practices (independent variable) and service quality (dependent variable) can be examined.

To identify the facilities management practitioners' perception on the supplier management for quality management practices as well as outsourcing service provider capabilities which will eventually impact service quality at a certain time point only, it is suggested for a cross-sectional study to be conducted as the data can be collected at one point in time (Sekaran \& Bougie, 2013). The various relationships of the research framework using a self-administered questionnaire (i.e. the respondents to respond to the survey in a natural environment with minimal interference from the researcher (Sekaran \& Bougie, 2010)) are examined through a correlation study. To test the proposed hypotheses, it is suggested for an analysis software of Smart-PLS 3.0 to be used.

To test the mediating effect of outsourcing service provider capabilities between supplier management for quality management practices and service quality, it is suggested for a mediation approach to be conducted based on Preacher and Hayes (2008). The basic approach of Baron and Kenny (1986) for testing the mediating effect has been widely adopted in the past. However, the mediation approach by Preacher and Hayes (2008) can estimate everything simultaneously instead of assuming the steps independently if the approach of Baron and Kenny (1986) is adopted. The approach of Preacher and Hayes (2008) can establish when the outsourcing service provider capabilities mediate the relationship between predicting and outcome variables such as supplier management for quality management practices and service quality. Both the relationships of the predicting variable to the mediator and of the mediator to the outcome variable must be significant with more than the 0.05 level (MacKinnon, Fairchild, \& Fritz, 2007). Apart from significance, Hair, Ringle, and Sarstedt (2011) indicated that the value of Variance Accounted For (VAF) can determine the strength of the mediation which are; (1) VAF value less than $20 \%$ means no mediation; (2) VAF value more than $20 \%$ but less than $80 \%$ means a partial mediation; (3) VAF value more than $80 \%$ means full mediation. According to Preacher and Hayes (2008), when the lower and upper limits of the confidence interval do not straddle a zero in the range, the mediating effect can be confirmed.

\section{CONCLUSION}

In a highly competitive business environment, there are various challenges in operating the business. The best management practices such as appropriate supplier management for quality management practices adopted by the facilities management practitioners, high outsourcing service provider capabilities should enhance the business outcomes. This paper attempts to provide a critical review to highlight and emphasize supplier management as an important quality management practice particularly in facilities management practitioners. They can influence outsourcing service providers and motivate them to perform good services through high outsourcing service provider capabilities, which ultimately enhances service quality. Based on the proposed empirical research, outsourcing service provider capabilities can be tested to confirm whether it can perform a mediating role between supplier management for quality management practices and service quality of facilities management companies.

\section{REFERENCES}

Akgün, A. E., Ince, H., Imamoglu, S. Z., Keskin, H., \& Kocoglu, İ. (2014). The mediator role of learning capability and business innovativeness between total quality management and financial performance. International Journal of Production Research, 52(3), 888-901.

Al-Hawary, S. I. S., \& Abu-Laimon, A. A. A. (2013). The impact of TQM practices on service quality in cellular communication companies in Jordan. International Journal of Productivity and Quality Management, 11(4), 446-474.

Alexander, K. (2003). A strategy for facilities management. Facilities, 21(11-12), 269-274.

Baron, R. M., \& Kenny, D. A. (1986). The moderator-mediator variable distinction in social psychological research: Conceptual, strategic, and statistical considerations. Journal of personality and social psychology, 51(6), 1173-1182.

Chuah, P., Wong, W. P., Ramayah, T., \& Jantan, M. (2010). Organizational context, supplier management practices and supplier performance: A case study of a multinational company in Malaysia. Journal of Enterprise Information Management, 23(6), 724758.

Gainey, T. W., \& Klaas, B. S. (2003). The Outsourcing ofTraining and Development: Factors Impacting Client Satisfaction. Management, 29(2), 207-229.

Gilley, K. M., \& Rasheed, A. (2000). Making more by doing less: an analysis of outsourcing and its effects on firm performance. Journal of management, 26(4), 763-790.

Goles, T. (2003). Vendor capabilities and outsourcing success: A resource-based view. Wirtschaftsinformatik, 45(2), 199-206.

Gottschalk, P., \& Solli-Sæther, H. (2005). Critical success factors from IT outsourcing theories: an empirical study. Industrial Management \& Data Systems, 105(6), 685-702. doi:10.1108/02635570510606941

Hair, J. F., Ringle, C. M., \& Sarstedt, M. (2011). PLS-SEM: Indeed a silver bullet. Journal of Marketing theory and Practice, 19(2), 139-152. 
Hallen, L., Johanson, J., \& Seyed-Mohamed, N. (1991). Interfirm Adaptation in Business Relationships. Marketing, 55(2), $29-37$.

Holcomb, T. R., \& Hitt, M. A. (2007). Toward a model of strategic outsourcing. Journal of Operations Management, 25(2), 464-481. doi:10.1016/j.jom.2006.05.003

Hong, J., Zhang, Y., \& Ding, M. (2018). Sustainable supply chain management practices, supply chain dynamic capabilities, and enterprise performance. Journal of Cleaner Production, 172, 3508-3519.

Hsu, C. C., Tan, K. C., Kannan, V. R., \& Keong Leong, G. (2009). Supply chain management practices as a mediator of the relationship between operations capability and firm performance. International Journal of Production Research, 47(3), 835-855.

Lee, J. N., Huynh, M. Q., Kwok, R. C. W., \& Pi, S. M. (2000). The evolution of outsourcing research: what is the next issue? Paper presented at the Proceedings of the 33rd Annual Hawaii International Conference on System Sciences.

Lehtonen, T., \& Salonen, A. (2006). An empirical investigation of procurement trends and partnership management in FM services A Finnish Survey. Strategic Property Management, 10(2), 65-78.

Lewis, B. R. (1993). Service quality measurement. Marketing Intelligence \& Planning, 11(4), 4-12.

Logan, M. S. (2000). Using Agency Theory to Design Successful Outsourcing Relationships The International Journal of Logistics Management, 11(2), 21-32.

MacKinnon, D. P., Fairchild, A. J., \& Fritz, M. S. (2007). Mediation analysis. Annu. Rev. Psychol., 58, 593-614.

McBlaine, R., \& Moritz, D. (2002). Transformational outsourcing: Delivering on the promise. Coporate Real Estate, 5(1), 57-64.

Mentzer, J. T., Min, S., \& Zacharia, Z. G. (2000). The Nature of Interfirm Partnering in Supply Chain Management. Retailing, 76(4), 549-568.

Ouakouak, M. L., Ouedraogo, N., \& Mbengue, A. (2014). The mediating role of organizational capabilities in the relationship between middle managers' involvement and firm performance: A European study. European Management Journal, 32(2), 305-318.

Parasuraman, A., Zeithaml, V. A., \& Berry, L. L. (1985). A Conceptual Model of Service Quality and Its Implications for Future Research. Marketing, 49, 41-50.

Parasuraman, A., Zeithaml, V. A., \& Leonard, L. B. (1988). SERVQUAL: A Multiple-Item Scale for Measuring Consumer Perceptions of Service Quality. Retailing, 64(1).

Peng, J., Quan, J., Zhang, G., \& Dubinsky, A. J. (2016). Mediation effect of business process and supply chain management capabilities on the impact of IT on firm performance: Evidence from Chinese firms. International Journal of Information Management, 36(1), 89-96.

Perunović, Z., Christoffersen, M., \& Mefford, R. N. (2012). Deployment of vendor capabilities and competences throughout the outsourcing process. International Journal of Operations \& Production Management, 32(3), 351-374.

Perunović, Z., Mefford, R., \& Christoffersen, M. (2012). Impact of information technology on vendor objectives, capabilities, and competences in contract electronic manufacturing. International Journal of Production Economics, 139(1), 207-219.

Peteraf, M. A., \& Barney, J. B. (2003). Unraveling the resource-based tangle. Managerial and Decision Economics, 24, $309-323$.

Plugge, A., Bouwman, H., \& Molina-Castillo, F. J. (2013). Outsourcing capabilities, organizational structure and performance quality monitoring: Toward a fit model. Information \& Management, 50(6), 275-284. doi:10.1016/j.im.2013.04.006

Prajogo, D., Chowdhury, M., Yeung, A. C. L., \& Cheng, T. C. E. (2012). The relationship between supplier management and firm's operational performance: A multi-dimensional perspective. International Journal of Production Economics, 136(1), 123-130.

Pratap, S. (2014). Towards a framework for performing outsourcing capability. Strategic Outsourcing: An International Journal, 7(3), 226-252. doi:10.1108/so-04-2014-0004

Preacher, K. J., \& Hayes, A. F. (2008). Asymptotic and resampling strategies for assessing and comparing indirect effects in multiple mediator models. Behavior research methods, 40(3), 879-891.

Ranganathan, C., \& Balaji, S. (2007). Critical Capabilities for Offshore Outsourcing of Information Systems. MIS Quarterly Executive, $6(3), 147-164$

Sekaran, U. (2010). Research methods for business : a skill-building approach (5th ed. ed.). Chichester: Wiley.

Sekaran, U. (2013). Research methods for business : a skill-building approach (6th ed. ed.). Chichester, West Sussex: Wiley.

Talib, F., Rahman, Z., \& Qureshi, M. N. (2013). An empirical investigation of relationship between total quality management practices and quality performance in Indian service companies. International Journal of Quality \& Reliability Management, 30(3), 280318.

Tan, K. C. (2002). Supply chain management: practices, concerns, and performance issues. Journal of Supply Chain Management, $38(4), 42-53$

Tseng, S. M. (2016). Knowledge management capability, customer relationship management, and service quality. Journal of Enterprise Information Management(29(2)), 202-221.

Tseng, S. M., \& Lee, P. S. (2014). The effect of knowledge management capability and dynamic capability on organizational performance. Journal of Enterprise Information Management, 27(2), 158-179.

Vickery, S. K., Jayaram, J., Droge, C., \& Calantone, R. (2003). The effects of an integrative supply chain strategy on customer service and financial performance: an analysis of direct versus indirect relationships. Journal of Operations Management, 21(5), 523539.

Wisner, J. D. (2003). A structural equation model of supply chain management strategies and firm performance. Journal of Business logistics, 24(1), 1-26.

Wong, W. P., \& Wong, K. Y. (2008). A review on benchmarking of supply chain performance measures. Benchmarking: An international journal, 15(1), 25-51.

Zakuan, N. M., Yusof, S. M., Laosirihongthong, T., \& Shaharoun, A. M. (2010). Proposed relationship of TQM and organisational performance using structured equation modelling. Total quality management, 21(2), 185-203.

Zineldin, M., \& Jonsson, P. (2000). An examination of the main factors affecting trust/commitment in supplier-dealer relationships: an empirical study of the Swedish wood industry. The TQM Magazine, 12(4), 245-265. 


\section{ACKNOWLEDGEMENT}

The authors would like to thank the Editorial Board publish this paper.

\section{AUTHORS' BIOGRAPHY}

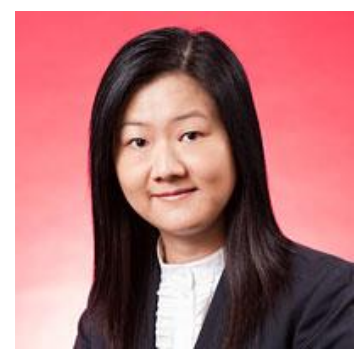

Conny Wang is currently pursuing PhD in Graduate School of Business, Universiti Sains Malaysia. Her area of interests includes service quality, facilities management and outsourcing.

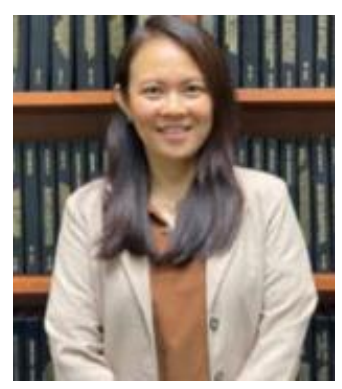

Dr. Cheng Ling Tan is an associate professor and deputy dean of the Graduate School of Business at the Universiti Sains Malaysia. She provides lectures on operations management and supervises postgraduate students in the field of innovations and operations management. Her research has been cited in many international journals.

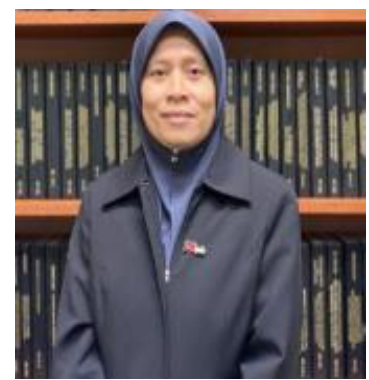

Dr. Nabsiah Abdul Wahid is a Professor of Marketing at Graduate School of Business, USM. She obtained her PhD from the University of New South Wales, Sydney, Australia. Her area of expertise is in marketing particularly consumer behaviour, services marketing, services quality, environmental and green marketing. 